\title{
Synthesis and evaluation of new thiazole-containing rhodanine-3-alkanoic acids as inhibitors of protein tyrosine phosphatases and glutathione $S$-transferases
}

\author{
Oleksandr L. Kobzar, Vitaliy O. Sinenko, Yuriy V. Shulha, Vladyslav M. Buldenko, \\ Diana M. Hodyna, Stepan G. Pilyo, Volodymyr S. Brovarets and Andriy I. Vovk* \\ V. P. Kukhar Institute of Bioorganic Chemistry and Petrochemistry of the NAS of Ukraine, 1 Murmanska St., Kyiv, 02094, Ukraine
}

\begin{abstract}
Thiazole-containing derivatives of rhodanine-3-alkanoic acids with propanoic or undecanoic acid groups were synthesized and evaluated as inhibitors of some protein tyrosine phosphatases and glutathione $S$-transferases. The rhodanines bearing longer carboxylated $\mathrm{N}$-alkyl chain were found to inhibit PTP1B, MEG1, MEG2, and VE-PTP as well as GST from equine liver and GSTA1-1 with IC50 values in the low micromolar range. The inhibitory effect on protein tyrosine phosphatase activity depends on substituent at position 2 of the thiazole ring. The best compound showed a competitive type of VE-PTP inhibition. In case of GST from equine liver, the inhibition was of mixed or non-competitive type with respect to glutathione or CDNB substrate, respectively. Possible binding modes of the inhibitors were discussed based on molecular docking calculations.
\end{abstract}

Keywords: rhodanine; thiazole; protein tyrosine phosphatase; glutathione $S$-transferase; enzyme inhibition; molecular docking.

\section{Introduction}

Thiazole derivatives represent a number of natural and synthetic biologically active compounds with anticancer [1], antibacterial [2], and antiviral activities [3]. Many of rhodanine-based compounds turned out to have low toxicity, exhibit antidiabetic, anti-inflammatory, antiAlzheimer's, anticancer, antibacterial, antifungal, and antiviral activities [4]. The best known anti-hyperglycemic, hypoglycemic and hypolipidemic effects of rhodanine derivatives are based on their agonist activity against PPARs and FFAR1 receptors, as well as inhibition of ALR2, PTP1B, and $\alpha$-glucosidase [5]. Anticancer activity of the compounds can be attributed to the inhibition capacity against pan-PIM kinases [6-7], protooncogene transcription factor $c$-Myc [8-9], protein disulfide isomerase (PDI) [10], histone acetyltransferases [11], topoisomera-

\begin{tabular}{ll}
\hline Received: & 22.10 .2020 \\
Revised: & 29.10 .2020 \\
Accepted: & 05.11 .2020 \\
Published online: & 30.12 .2020 \\
\hline
\end{tabular}

* Corresponding author. Tel.: +380-44-558-5388;

e-mail:vovk@bpci.kiev.ua (A. I. Vovk)

ORCID: 0000-0001-6167-076X se II [11], as well as Bcl-XL and Mcl-1 families of the proteins [13]. Antibacterial effects of rhodanine derivatives can be realized via inhibition of bacterial penicillin-binding proteins [14] and $\beta$-lactamases [15-16].

The protein tyrosine dephosphorylation is a fundamental regulatory mechanism of many signal transduction pathways in processes of growth, proliferation, differentiation, or survival of eukaryotic cells. It was shown that elevated activity of classical non-receptor and receptorlike protein tyrosine phosphatases (PTPs) coincides with a number of pathologies [17-18]. PTP1B, being a negative regulator of insulin and leptin signaling is considered as a promising therapeutic target for treatment of type 2 diabetes and obesity [19]. Overexpression of this phosphatase was also found to contribute to tumorigenesis of cells [20-21]. Megakaryocyte protein tyrosine phosphatase MEG-2 which involved in regulating of hematopoietic signaling and blood glucose homeostasis is of interest as a therapeutic target for treatment of type 2 diabetes and myeloproliferative disorders [23-25]. PTP $\beta$, also called as vascular endothelialprotein tyrosine phosphatase (VE-PTP), downregulates Tie2 signaling and often associated with development of variety endothelial dysfunctions. In this connection, a number of chemical compounds were developed as inhibitors of the protein tyrosine phosphatases.

(C) Kobzar O. L. et al. This is an open-access article distributed under the terms of the Creative Commons Attribution License, which permits unrestricted use, distribution, and reproduction in any medium, provided the original author and source are credited. 
Among them, aryl and hetaryl compounds [26], including derivatives of rhodanine [27-29] and its closely related analog, thiazolidinedione [30-31], were studied as PTPs inhibitors. Compounds bearing carboxylic [32], phosphonic [33-34], sulfonic groups [35] were designed as pTyr mimetics for inhibition of PTP1B. As a drug for treatment of diabetic macular edema, diabetic retinopathy, and ocular hypertension, the inhibitor of VE-PTP AKB-9778/Razuprotafib was developed [36-38].

It was reported previously that thiazolyl-2,4thiazolidinedione/rhodanine compounds possess anticancer activities against hepatocellular carcinoma cell lines having resistance to chemotherapeutic agents [39]. The drug resistance caused by drug-metabolizing enzymes is considered a serious problem in treatment of cancer diseases [40]. Glutathione $S$-transferases (GSTs) comprise a superfamily of multifunctional phase II detoxification enzymes catalyzing the conjugation of glutathione (GSH) with a variety of exogenous and endogenous xenobiotics. The glutathione conjugates having less cytotoxicity and greater hydrophilicity excreted from the cells via the mercapturic acid pathway [41]. Overexpression of GSTs was noticed in a number of tumor cases [42-44]. Chemotherapeutic alkylating agents such as busulfan, melphalan, chlorambucil, brostallicin, and immunosuppressant azathioprine described as the substrates of these enzymes. Therefore, many compounds including analogs of glutathione and its conjugates as well as derivatives of benzoquinone, benzophenone, nitrobenzoxadiazole, and curcumin were designed as inhibitors of GSTs [41-44].

Previously, a series of rhodanine-3-alkanoic acid derivatives were described as potential inhibitors of protein tyrosine phosphatase [45]. In the current study, we report synthesis of thiazole-containing rhodanine-3-alkanoic acids and their in vitro evaluation as inhibitors of PTPs and GSTs.

\section{Results and discussion}

Synthesis of 5-(thiazol-5-ylmethylene)-2-thioxothiazolidin-4-one derivative

The synthesis of thiazole-containing rhodanine-3carboxyalkyl acids 3a-f is outlined in Scheme 1. The compounds were obtained by Knoevenagel condensation of corresponding rhodanines with aldehydes. Ethanol solution containing a proper 1,3-thiazolecarbaldehyde (compounds 1a-c), $N$-alkyl carboxylated rhodanine (compounds $\mathbf{2 a}, \mathbf{b}$ ), and 2-aminoethanol was heated for $3 \mathrm{~h}$. The obtained precipitate was filtered off and recrystallized from ethanol [46]. The compounds were obtained in moderate to good yield and were characterized by ${ }^{1} \mathrm{H} \mathrm{NMR},{ }^{13} \mathrm{C} \mathrm{NMR}$ and mass spectra. The data of NMR spectra showed that the newly synthesized compounds are represented by one of two $\mathrm{Z} / \mathrm{E}$ isomeric forms. It should be noted that similar thiazole-contained rhodanine derivatives were described as Z-isomers [39].

Biological evaluation of thiazole-containing rhodanine-3-alkanoic acids as inhibitors of protein tyrosine phosphatases and glutathione S-transferases

Human recombinant protein tyrosine phosphatases PTP1B, VE-PTP, MEG1, and MEG2 were used for in vitro assays of the synthesized thiazole-containing rhodanine-3carboxyalkyl acids 3a-f. Values of the half maximal inhibitory concentrations $\left(\mathrm{IC}_{50}\right)$ for the compounds are presented in Table 1.

As can be seen from Table 1, rhodanine derivatives 3a-c containing shorter alkyl carboxylated group were less effective inhibitors of PTPs than derivatives 3d-f bearing longer $N$-alkyl chain. Compound 3a, which possesses butyric acid fragment in $N-3$ position of rhodanine scaffold and phenyl substituent at $C$-2 position of 1,3-thiazol-5ylmethylene moiety, was found to be a weak inhibitor of

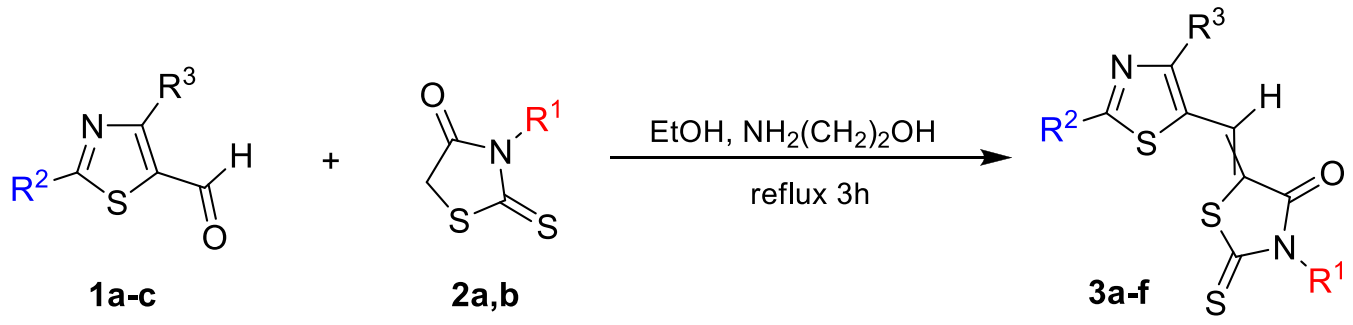

\begin{tabular}{|c|c|c|c|}
\hline & $\mathrm{R}^{1}$ & $\mathrm{R}^{2}$ & $\mathrm{R}^{3}$ \\
\hline $3 \mathbf{a}$ & $\left(\mathrm{CH}_{2}\right)_{3}-\mathrm{COOH}$ & $\mathrm{Ph}$ & $\mathrm{H}$ \\
\hline $3 \mathbf{b}$ & $\left(\mathrm{CH}_{2}\right)_{3}-\mathrm{COOH}$ & $\mathrm{C}_{6} \mathrm{H}_{4}-\mathrm{p}-\mathrm{Cl}$ & $\mathrm{H}$ \\
\hline $3 c$ & $\left(\mathrm{CH}_{2}\right)_{3}-\mathrm{COOH}$ & $\mathrm{N}\left(\mathrm{CH}_{3}\right)_{2}$ & $\mathrm{Ph}$ \\
\hline 3d & $\left(\mathrm{CH}_{2}\right)_{10}-\mathrm{COOH}$ & $\mathrm{Ph}$ & $\mathrm{H}$ \\
\hline $3 \mathbf{e}$ & $\left(\mathrm{CH}_{2}\right)_{10}-\mathrm{COOH}$ & $\mathrm{C}_{6} \mathrm{H}_{4}-\mathrm{p}-\mathrm{Cl}$ & $\mathrm{H}$ \\
\hline $3 f$ & $\left(\mathrm{CH}_{2}\right)_{10}-\mathrm{COOH}$ & $\mathrm{N}\left(\mathrm{CH}_{3}\right)_{2}$ & $\mathrm{Ph}$ \\
\hline
\end{tabular}

Scheme 1. Synthesis of thiazole-containing rhodanine-3-alkanoic acids. 
Table 1. $\mathrm{IC}_{50}$ values of thiazole-containing rhodanine derivatives $\mathbf{3 a - f}$ as inhibitors of protein tyrosine phosphatases*

\begin{tabular}{c|c|c|c|c}
\hline \multirow{2}{*}{ Compd } & \multicolumn{4}{|c}{$\mathrm{IC}_{50}, \mu \mathrm{M}$} \\
\cline { 2 - 5 } & PTP1B & MEG1 & MEG2 & VE-PTP \\
\hline 3a & $>25$ & $>25$ & $>25$ & $>25$ \\
3b & $17.0 \pm 4.4$ & $>25$ & $18.7 \pm 3.2$ & $>25$ \\
3c & $>25$ & $>25$ & $>25$ & $>25$ \\
3d & $4.1 \pm 1.2$ & $23.1 \pm 3.9$ & $2.4 \pm 0.4$ & $2.4 \pm 0.7$ \\
3e & $0.82 \pm 0.17$ & $12.4 \pm 3.5$ & $0.54 \pm 0.12$ & $0.43 \pm 0.07$ \\
3f & $2.5 \pm 0.6$ & $11.0 \pm 1.4$ & $2.4 \pm 0.5$ & $3.1 \pm 0.6$ \\
\hline
\end{tabular}

${ }^{*} \mathrm{IC} \mathrm{C}_{50}$ values represent the mean of $2-3$ assays \pm standard deviation.

PTPs. The introduction of a chlorine substituent into the para-position of phenyl group of this rhodanine derivative slightly increases inhibitory effects of compound $\mathbf{3 b}$ against PTP1B and MEG2. However, the replacement of 4-chlorophenyl residue by dimethylamino one, as well as introduction of phenyl group at $C$-4 position of 1,3-thiazol5-ylmethylene moiety (compound 3c) caused a decrease in inhibitory effects. The rhodanine derivative $\mathbf{3 d}$ bearing undecanoic acid fragment at position N-3 showed significant increase in inhibition of PTP1B, VE-PTP, and MEG2 as compared to structure of compound 3a with butyric acid fragment. Similarly to the effects obtained for rhodanine derivative $\mathbf{3 b}$, the introduction of chlorine atom in the para-position of phenyl group of 1,3-thiazol-5ylmethylene moiety of compound 3d led to increased inhibitory potential of rhodanine derivative $3 \mathbf{e}$. $\mathrm{IC}_{50}$ values of this compound were $0.82 \mu \mathrm{M}, 0.54$, and $0.43 \mu \mathrm{M} \mu \mathrm{M}$ for PTP1B, MEG2, and VE-PTP, respectively.

Kinetic studies were carried out to elucidate the possible mechanism of protein tyrosine phosphatases inhibition by the thiazole-containing rhodanine derivatives. According to Lineweaver-Burk plots (Figure 1), compound $\mathbf{3 e}$ is a competitive-type inhibitor of protein tyrosine phosphatase
VE-PTP with the calculated value of inhibition constant $K_{\mathrm{i}}$ of $0.20 \mu \mathrm{M}$.

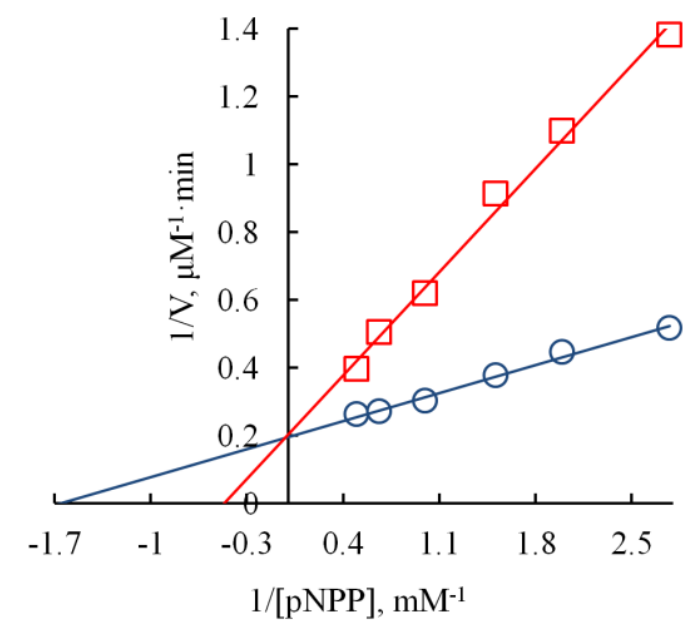

Figure 1. Lineweaver-Burk plots for inhibition of VE-PTP by compound 3e. The inhibitor concentrations were $0(0)$ and $0.5 \mu \mathrm{M}$ (口).
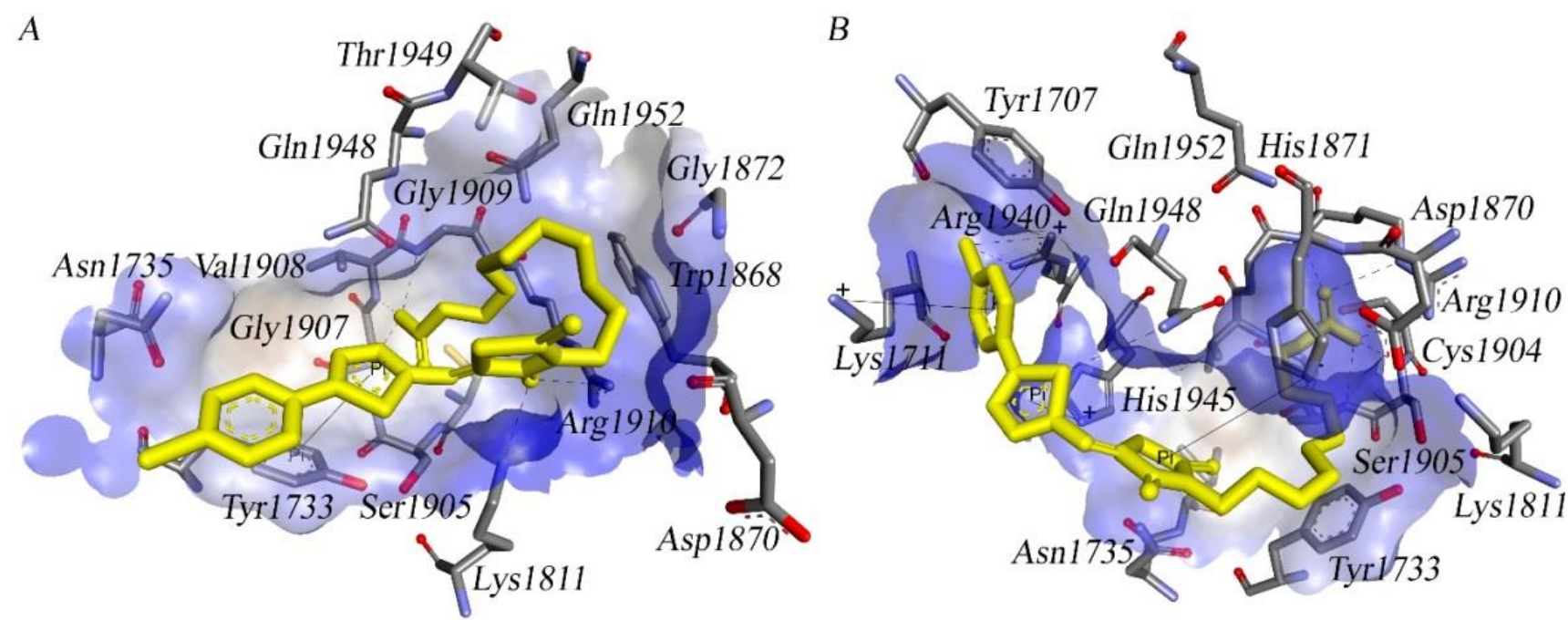

Figure 2. Possible binding modes of rhodanine derivative 3e to human recombinant VE-PTP with open (A) and closed (B) conformations. 
Molecular docking was performed to predict possible binding mode of carboxylated rhodanine derivative with PTPs. Synthetic studies described 5-ene-rhodanines mainly as Z-isomeres [4, 39]. In this connection, Z-isomer of compound $3 \mathbf{e}$ was chosen to be docked into the active site region of the open and closed conformations of human VE-PTP. The estimated affinity of carboxylated rhodanine derivative $3 \mathbf{e}$ to the active site of VE-PTP in open conformation was found to be $-5.9 \mathrm{kcal} / \mathrm{mol}$. The rhodanine scaffold of the inhibitor formed hydrogen bonds with amino acids residues of Lys1811 and Arg1910. The carboxylic group of the alkyl chain occupies active site near catalytic Cys1904 forming hydrogen bonds with amino acid residues Ala1906, Gly1906, Val1908, and Gly1909, while thiazole ring provided $\pi$-stacking interaction with Tyr1733 (Figure 2A).

In case of closed enzyme conformation, the estimated binding energy was $-6.4 \mathrm{kcal} / \mathrm{mol}$. The obtained model indicates that compound may be oriented into the active site of VE-PTP by carboxylic group of alkyl chain. This fragment form hydrogen bonds with amino acid residues Ser1905, Ala1906, and Arg1910. The thiazole ring of compound $\mathbf{3 e}$ is involved in hydrogen bond formation with Gln 1948 and $\pi$-cation interaction with His 1945. The 2-chlorophenyl group forms $\pi$-cation interactions with Lys1711 and Arg1940 as well as halogen bond of chlorine atom with $\operatorname{Arg} 1940$ (Figure 2B).

The thiazole-containing rhodanine-3-carboxyalkyl acids were studied as inhibitors of GST from equine liver and human recombinant GSTA1-1. The obtained results (Table 2) demonstrated that compounds 3d-f were more potent inhibitors in comparison with derivatives 3a-c bearing butyric acid fragment at $\mathrm{N}-3$ position of rhodanine scaffold. Better inhibition effects against GST from equine liver were observed in the case of compounds 3d-f modified at $N-3$ position of rhodanine ring with undecanoic acid group. Further studies showed that these compounds can also inhibit the recombinant form of human GSTA1-1 with $\mathrm{IC}_{50}$ values in the low micromolar range.

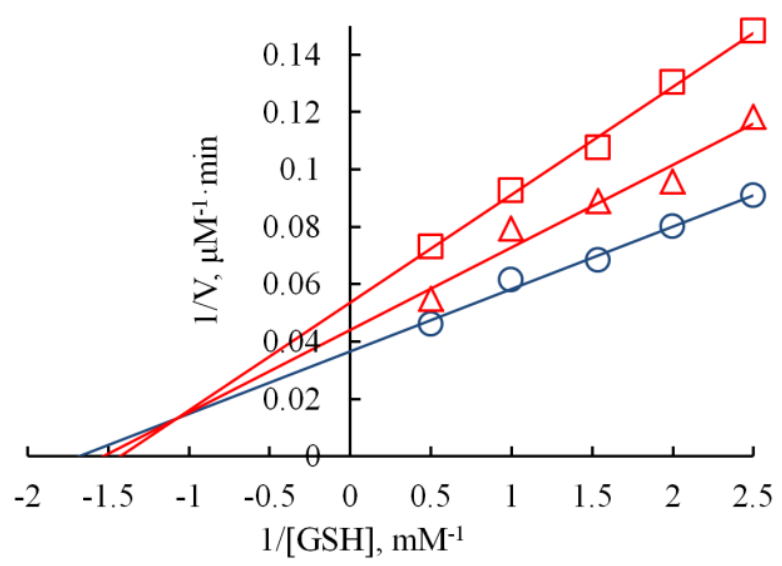

Table 2. Inhibition activity of 5-(thiazol-5-ylmethylene)-2thioxothiazolidin-4-one derivatives 3a-f against GST from equine liver and human recombinant GSTA1-1*.

\begin{tabular}{c|c|c}
\hline \multirow{2}{*}{ Compd } & \multicolumn{2}{|c}{$\mathrm{IC}_{50}, \mu \mathrm{M}$} \\
\cline { 2 - 3 } & GST from equine liver & GSTA1-1 \\
\hline 3a & $>25$ & - \\
3b & $24.1 \pm 2.7$ & - \\
3c & $>25$ & - \\
3d & $5.2 \pm 1.4$ & $1.1 \pm 0.2$ \\
3e & $4.5 \pm 0.5$ & $0.83 \pm 0.22$ \\
3f & $6.2 \pm 0.9$ & $2.7 \pm 0.7$ \\
\hline
\end{tabular}

${ }^{*} \mathrm{IC}_{50}$ values are the means of 2-3 assays \pm standard deviation.

Lineweaver-Burk plots (Figure 3) showed mixed-type or non-competitive inhibition of GST from equine liver by compound 3d toward glutathione or CDNB substrate. According to the mixed-type inhibition, the calculated values of inhibition constants $K_{\mathrm{i}}$ and $K_{\mathrm{i}}^{\prime}$ were $12.9 \pm 3.7 \mu \mathrm{M}$ and $20.2 \pm 5.8 \mu \mathrm{M}$, respectively, while the non-competitive inhibition constant $K_{\mathrm{i}}$ was $6.8 \pm 1.8 \mu \mathrm{M}$.

The results of computer modeling suggest that $Z$-isomer of rhodanine derivative 3d may occupy interdomain cavity near active site of human GSTA1-1 (Figure 4A) with the calculated docking energy of $-9.3 \mathrm{kcal} / \mathrm{mol}$. Deregulation of the interdomain contacts in structure of GSTA1-1 was shown to lead to disruption of the enzyme catalytic functions [47] which may explain the inhibition of the enzyme. The compound position (Figure 4B) is characterized by interaction of the inhibitor with hydrophobic amino acid residues Thr68, Leu72, Ile96, Ile99, Ala100, Ile106, Leu107, and Leu163. Thiazole ring at $C-5$ position of rhodanine scaffold formed $\pi$-stacking interaction with Tyr166, while phenyl fragment at $C-2$ position of the thiazole ring provided $\pi$-cation interaction with Arg13. Hydrogen bond was observed between oxygen atom of rhodanine scaffold and Ser18. Carboxylate group of the inhibitor is adjacent to the active G-site and provides

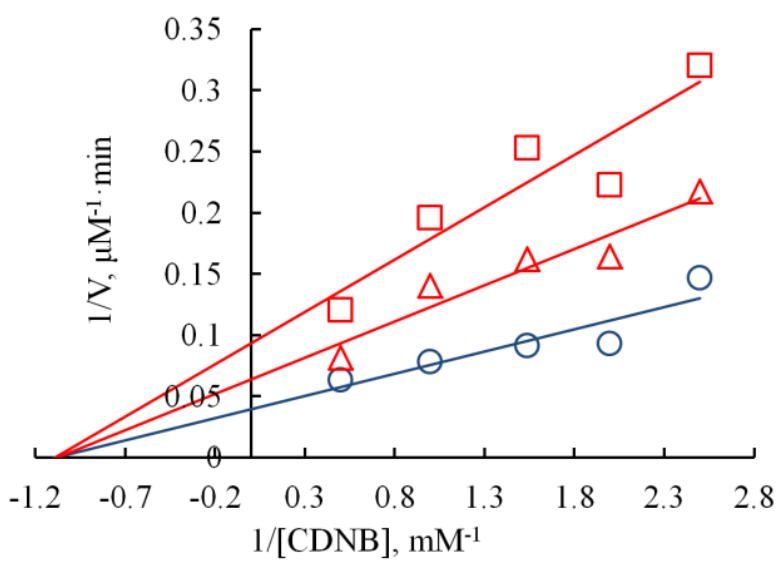

Figure 3. Lineweaver-Burk plots for inhibition of GST from equine liver by compound 3d. The inhibitor concentrations were 0 (०), $5 \mu \mathrm{M}(\Delta)$ and $7.5 \mu \mathrm{M}(\square)$. 

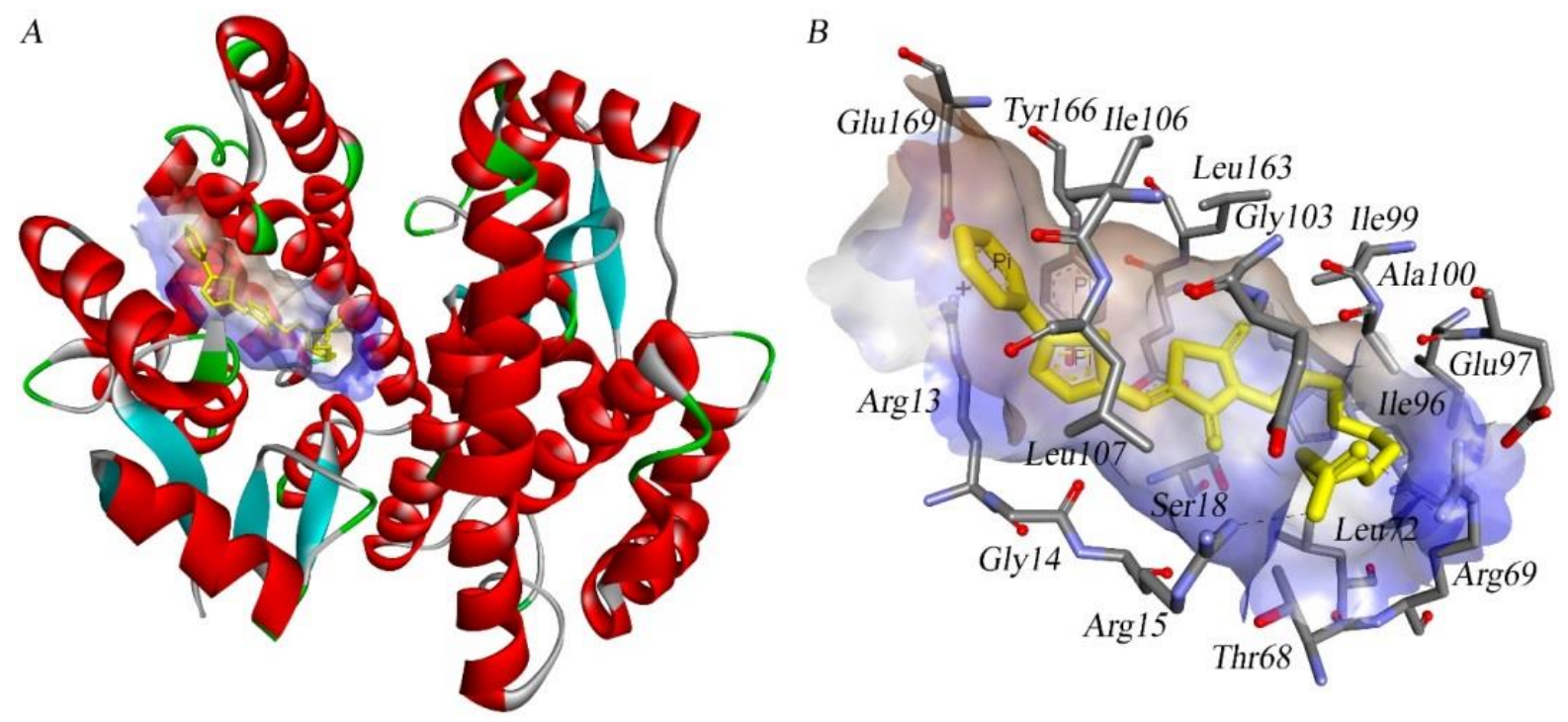

Figure 4. Possible binding mode of rhodanine derivative 3d to homodimer structure of human GSTA1-1.

hydrogen bonds with amino acid residues Arg69 and Arg15 which is involved in interaction with GSH.

\section{Conclusions}

The study reported synthesis of new rhodanine-3alkanoic acids with propanoic or undecanoic acid groups. The data obtained showed that compounds 3d-f bearing undecanoic acid group at $N-3$ position of rhodanine scaffold possess good inhibitory effects against PTP1B, MEG1, MEG2, and VE-PTP as well as GSTA1-1. According to kinetic data, thiazole-containing rhodanines can be competitive-type inhibitors of VE-PTP. In case of GST from equine liver, the compounds can be considered as mixed-type inhibitors toward GSH and non-competitive toward CDNB substrate. Molecular docking results indicate that the inhibitors may occupy VE-PTP active site, while inhibition of GSTA1-1 might be explained by the location of rhodanine derivative between $C$ - and $N$-terminal subunits of the enzyme.

\section{Experimental section}

\section{Chemistry}

${ }^{1} \mathrm{H}(500 \mathrm{MHz})$ and ${ }^{13} \mathrm{C}(125 \mathrm{MHz}) \mathrm{NMR}$ spectra were recorded on Bruker Avance DRX 500 spectrometer in DMSO- $d_{6}$ solution. IR spectra were recorded on a Vertex 70 spectrometer from $\mathrm{KBr}$ pellets. Melting points were measured with a Büchi melting point apparatus and are uncorrected. LC-MS spectra were obtained using HPLC apparatus, Agilent 1100 Series, equipped with diode-matrix and mass-selective detector Agilent LC/MSD SL.

\section{General procedure for synthesis of compounds $3 a-f$}

A solution of $0.002 \mathrm{~mol}$ of rhodanine derivative $\mathbf{2 a}$ or $\mathbf{2 b}$ in $5 \mathrm{~mL}$ of ethanol and $0.02 \mathrm{~mL}$ of 2-aminoethanol were added to a solution of $0.002 \mathrm{~mol}$ of corresponding aldehyde $(\mathbf{1 a}-\mathbf{c})$ in $5 \mathrm{~mL}$ of ethanol. The mixture was refluxed for $3 \mathrm{~h}$ and cooled. The precipitate was filtered off and recrystallized from $\mathrm{EtOH}$.

4-\{4-Oxo-5-[(2-phenyl-1,3-thiazol-5-yl)methylidene]-2sulfanylidene-1,3-thiazolidin-3-yl\}butanoic acid (3a).

Yield: $0.531 \mathrm{~g}(68 \%)$; yelow crystals; mp 190-191 ${ }^{\circ} \mathrm{C}$. ${ }^{1} \mathrm{H}$ NMR (500 MHz, DMSO- $\left.d_{6}\right) \delta 12.11$ (br s, $1 \mathrm{H}, \mathrm{COOH}$ ), 8.48 (s, $1 \mathrm{H}, \mathrm{CH}), 8.12\left(\mathrm{~s}, 1 \mathrm{H}, \mathrm{C}^{4}-H_{\text {thiazol }}\right), 8.03(\mathrm{~d}, J 7.7 \mathrm{~Hz}$, $2 \mathrm{H}, \mathrm{Ph}), 7.49-7.59(\mathrm{~m}, 3 \mathrm{H}, \mathrm{Ph}), 4.06\left(\mathrm{t}, J 6.8 \mathrm{~Hz}, 2 \mathrm{H}, \mathrm{CH}_{2}\right)$, $2.30\left(\mathrm{t}, J 7.2 \mathrm{~Hz}, 2 \mathrm{H}, \mathrm{CH}_{2}\right), 1.84-1.95\left(\mathrm{~m}, 2 \mathrm{H}, \mathrm{CH}_{2}\right)$. ${ }^{13} \mathrm{C}$ NMR $\left(125 \mathrm{MHz}, \mathrm{DMSO}-d_{6}\right) \delta 192.5,174.1,172.8$, $166.8,151.2,133.7,132.6,132.0,129.9,127.1,123.7$, 123.2, 44.4, 31.4, 22.4. LC/MS (CI) m/z $391(\mathrm{M})^{+}$. Anal. Calcd. for $\mathrm{C}_{17} \mathrm{H}_{14} \mathrm{~N}_{2} \mathrm{O}_{3} \mathrm{~S}_{3}: \mathrm{C}, 52.29 ; \mathrm{H}, 3.61 ; \mathrm{N}, 7.17 ; \mathrm{S}$, 24.63. Found: C, 52.35; H, 3.60; N, 7.10; S, 24.64.

4-(5-\{[2-(4-Chlorophenyl)-1,3-thiazol-5-yl]methylidene -4-oxo-2-sulfanylidene-1,3-thiazolidin-3-yl)butanoic $\operatorname{acid}(3 \boldsymbol{b})$.

Yield: $0.484 \mathrm{~g}(57 \%)$; yelow crystals; $\mathrm{mp} 201-202^{\circ} \mathrm{C}$. ${ }^{1} \mathrm{H}$ NMR (500 MHz, DMSO-d $\left.d_{6}\right) \delta 12.12$ (br s, $1 \mathrm{H}, \mathrm{COOH}$ ), $8.47(\mathrm{~s}, 1 \mathrm{H}, \mathrm{CH}), 8.10\left(\mathrm{~s}, 1 \mathrm{H}, \mathrm{C}^{4}-H_{\text {thiazol }}\right), 8.02(\mathrm{~d}, J 8.5 \mathrm{~Hz}$, $\left.2 \mathrm{H}, \mathrm{C}_{6} \mathrm{H}_{4}-\mathrm{p}-\mathrm{Cl}\right), 7.56$ (d, J $\left.8.5 \mathrm{~Hz}, 2 \mathrm{H}, \mathrm{C}_{6} H_{4}-\mathrm{p}-\mathrm{Cl}\right), 4.05$ (t, $\left.J 6.8 \mathrm{~Hz}, 2 \mathrm{H}, \mathrm{CH}_{2}\right), 2.31\left(\mathrm{t}, J 7.1 \mathrm{~Hz}, 2 \mathrm{H}, \mathrm{CH}_{2}\right), 1.83-1.93$ $\left(\mathrm{m}, 2 \mathrm{H}, \mathrm{CH}_{2}\right) .{ }^{13} \mathrm{C} \mathrm{NMR}\left(125 \mathrm{MHz}, \mathrm{DMSO}-d_{6}\right) \delta 190.2$, $171.9,169.0,164.6,148.9,134.4,131.8,129.2,127.7$, $126.5,121.7,120.8,42.2,29.2,20.1$. LC/MS (CI) m/z 426 $(\mathrm{M})^{+}$. Anal. Calcd. for $\mathrm{C}_{17} \mathrm{H}_{13} \mathrm{ClN}_{2} \mathrm{O}_{3} \mathrm{~S}_{3}$ : C, 48.05; H, 3.08; $\mathrm{N}, 6.59 ; \mathrm{S}, 22.64$. Found: C, 48.14; H, 3.04; N, 6.53; S, 22.54 .

4-(5-\{[2-(Dimethylamino)-4-phenyl-1,3-thiazol-5-yl] methylidene \}-4-oxo-2-sulfanylidene-1,3-thiazolidin-3yl)butanoic acid (3c).

Yield: $0.702 \mathrm{~g}(81 \%)$; yelow crystals; $\mathrm{mp} 179-180{ }^{\circ} \mathrm{C}$. ${ }^{1} \mathrm{H}$ NMR (500 MHz, DMSO- $\left.d_{6}\right) \delta 7.63(\mathrm{~s}, 1 \mathrm{H}, \mathrm{CH}), 7.50-$ $7.62(\mathrm{~m}, 5 \mathrm{H}, \mathrm{Ph}), 3.98\left(\mathrm{t}, J 6.5 \mathrm{~Hz}, 2 \mathrm{H}, \mathrm{CH}_{2}\right), 3.20(\mathrm{~s}, 6 \mathrm{H}$, $\left.\mathrm{N}\left(\mathrm{CH}_{3}\right)_{2}\right), 2.16\left(\mathrm{t}, J 7.2 \mathrm{~Hz}, 2 \mathrm{H}, \mathrm{CH}_{2}\right), 1.74-1.87(\mathrm{~m}, 2 \mathrm{H}$, $\left.\mathrm{CH}_{2}\right) .{ }^{13} \mathrm{C} \mathrm{NMR}\left(125 \mathrm{MHz}, \mathrm{DMSO}-d_{6}\right) \delta 191.2,174.2$, 
$172.2,166.4,161.8,133.6,129.7,129.4,128.7,125.4$, 116.9, 113.8, 44.0, 41.7, 32.0, 22.5. LC/MS (CI) m/z 434 $(\mathrm{M})^{+}$. Anal. Calcd. for $\mathrm{C}_{19} \mathrm{H}_{19} \mathrm{~N}_{3} \mathrm{O}_{3} \mathrm{~S}_{3}$ : C, 52.64; H, 4.42; N, 9.69; S, 22.19. Found: C, 52.68; H, 4.39; N, 9.68; S, 22.12 .

11-\{4-Oxo-5-[(2-phenyl-1,3-thiazol-5-yl)methylidene]-2sulfanylidene-1,3-thiazolidin-3-yl\}undecanoic acid (3d).

Yield: $0.733 \mathrm{~g}(75 \%)$; yelow crystals; $\mathrm{mp} 141-142{ }^{\circ} \mathrm{C}$. ${ }^{1} \mathrm{H}$ NMR (500 MHz, DMSO- $\left.d_{6}\right) \delta 8.43(\mathrm{~s}, 1 \mathrm{H}, \mathrm{CH}), 8.07$ (s, $\left.1 \mathrm{H}, \mathrm{C}^{4}-H_{\text {thiazol }}\right), 7.99(\mathrm{~d}, J 8.1 \mathrm{~Hz}, 2 \mathrm{H}, \mathrm{Ph}), 7.46-7.56(\mathrm{~m}$, $3 \mathrm{H}, \mathrm{Ph}), 3.94$ (t, J $\left.7.3 \mathrm{~Hz}, 2 \mathrm{H}, \mathrm{CH}_{2}\right), 2.16$ (t, J $7.4 \mathrm{~Hz}$, $\left.2 \mathrm{H}, \mathrm{CH}_{2}\right), 1.54-1.64\left(\mathrm{~m}, 2 \mathrm{H}, \mathrm{CH}_{2}\right), 1.41-1.51(\mathrm{~m}, 2 \mathrm{H}$, $\left.\mathrm{CH}_{2}\right), 1.16-1.29\left(\mathrm{~m}, 12 \mathrm{H},\left(\mathrm{CH}_{2}\right)_{6}\right) .{ }^{13} \mathrm{C} \mathrm{NMR}(125 \mathrm{MHz}$, DMSO- $\left.d_{6}\right) \delta 192.1,174.9,172.8,166.6,151.3,133.6$, 132.6, 132.0, 129.8, 127.1, 123.5, 123.4, 44.9, 34.1, 29.3, 29.3, 29.2, 29.0, 29.0, 26.7, 26.6, 25.0. LC/MS (CI) m/z 489 $(\mathrm{M})^{+}$. Anal. Calcd. for $\mathrm{C}_{24} \mathrm{H}_{28} \mathrm{~N}_{2} \mathrm{O}_{3} \mathrm{~S}_{3}$ : C, 58.99; H, 5.78; $\mathrm{N}$, 5.73; S, 19.68. Found: C, 59.10; H, 5.73; N, 5.70; S, 19.69 .

11-(5-\{[2-(4-Chlorophenyl)-1, 3-thiazol-5-yl]methylidene -4-oxo-2-sulfanylidene-1,3-thiazolidin-3-yl)undecanoic $\operatorname{acid}(3 \boldsymbol{e})$.

Yield: $0.764 \mathrm{~g}(73 \%)$; yelow crystals; mp $173-174{ }^{\circ} \mathrm{C}$. ${ }^{1} \mathrm{H}$ NMR (500 MHz, DMSO-d $) \delta 11.76$ (br s, $\left.1 \mathrm{H}, \mathrm{COOH}\right)$, $8.41(\mathrm{~s}, 1 \mathrm{H}, \mathrm{CH}), 8.06\left(\mathrm{~s}, 1 \mathrm{H}, \mathrm{C}^{4}-H_{\text {thiazol }}\right), 7.99(\mathrm{~d}, J 7.7 \mathrm{~Hz}$, $\left.2 \mathrm{H}, \mathrm{C}_{6} \mathrm{H}_{4}-\mathrm{p}-\mathrm{Cl}\right), 7.54$ (d, J $\left.7.7 \mathrm{~Hz}, 2 \mathrm{H}, \mathrm{C}_{6} \mathrm{H}_{4}-\mathrm{p}-\mathrm{Cl}\right), 3.94-$ $4.00\left(\mathrm{~m}, 2 \mathrm{H}, \mathrm{CH}_{2}\right), 2.16\left(\mathrm{t}, J 7.4 \mathrm{~Hz}, 2 \mathrm{H}, \mathrm{CH}_{2}\right), 1.58-1.65$ (m, 2H, $\left.\mathrm{CH}_{2}\right), 1.44-1.51\left(\mathrm{~m}, 2 \mathrm{H}, \mathrm{CH}_{2}\right), 1.19-1.30(\mathrm{~m}, 12 \mathrm{H}$, $\left.\left(\mathrm{CH}_{2}\right)_{6}\right) .{ }^{13} \mathrm{C}$ NMR $\left(125 \mathrm{MHz}, \mathrm{DMSO}-d_{6}\right) \delta 189.8,172.4$, $169.1,164.4,148.9,134.4,131.8,129.3,127.7,126.5$, 121.7, 120.9, 42.7, 31.9, 27.0, 26.9, 26.9, 26.7, 26.7, 24.4, 24.3, 22.7. LC/MS (CI) m/z $524(\mathrm{M})^{+}$. Anal. Calcd. for $\mathrm{C}_{24} \mathrm{H}_{27} \mathrm{ClN}_{2} \mathrm{O}_{3} \mathrm{~S}_{3}$ : C, 55.10; H, 5.20; N, 5.35; S, 18.39 . Found: C, 55.14; H, 5.15; N, 5.32; S, 18.37.

11-(5-\{[2-(Dimethylamino)-4-phenyl-1,3-thiazol-5-yl]methylidene \}-4-oxo-2-sulfanylidene-1,3-thiazolidin-3yl)undecanoic acid (3f).

Yield: $0.744 \mathrm{~g}(70 \%)$; yelow crystals; $\mathrm{mp} 114-115^{\circ} \mathrm{C}$. ${ }^{1} \mathrm{H}$ NMR $\left(500 \mathrm{MHz}, \mathrm{DMSO}-d_{6}\right) \delta 7.67(\mathrm{~s}, 1 \mathrm{H}, \mathrm{CH}), 7.47-$ $7.63(\mathrm{~m}, 5 \mathrm{H}, \mathrm{Ph}), 3.89-3.99\left(\mathrm{~m}, 2 \mathrm{H}, \mathrm{CH}_{2}\right), 3.21(\mathrm{~s}, 6 \mathrm{H}$, $\left.\mathrm{N}\left(\mathrm{CH}_{3}\right)_{2}\right), 2.15\left(\mathrm{t}, J 6.6 \mathrm{~Hz}, 2 \mathrm{H}, \mathrm{CH}_{2}\right), 1.54-1.62(\mathrm{~m}, 2 \mathrm{H}$, $\left.\mathrm{CH}_{2}\right), 1.42-1.50\left(\mathrm{~m}, 2 \mathrm{H}, \mathrm{CH}_{2}\right), 1.16-1.29\left(\mathrm{~m}, 12 \mathrm{H},\left(\mathrm{CH}_{2}\right)_{6}\right)$. ${ }^{13} \mathrm{C}$ NMR (125 MHz, DMSO- $\left.d_{6}\right) \delta 189.3,172.5,170.5$, $164.5,160.0,131.9,127.6,126.9,123.7,123.6,115.1$, 112.0, 42.5, 32.0, 26.9, 26.9, 26.8, 26.8, 26.7, 26.6, 24.5, 24.3, 22.8. LC/MS (CI) m/z $532(\mathrm{M})^{+}$. Anal. Calcd. for $\mathrm{C}_{26} \mathrm{H}_{33} \mathrm{~N}_{3} \mathrm{O}_{3} \mathrm{~S}_{3}$ : C, 58.73; H, 6.26; N, 7.90; S, 18.09. Found: C, 58.79; H, 6.26; N, 7.84; S, 18.03 .

\section{Biological tests}

In vitro study of thiazole-containing rhodanine-3alkanoic acid derivatives as inhibitors of protein tyrosine phosphatases and glutathione S-transferases

Protein tyrosine phosphatases were purchased in SigmaAldrich. Prior to experiments, the defined volume of PTP1B, VE-PTP, MEG1 and MEG2 were diluted in a solution of $50 \mathrm{mM}$ Bis-Tris buffer ( $\mathrm{pH}$ 7.2) containing $30 \%$ glycerol, $3 \mathrm{mM}$ EDTA, $2 \mathrm{mM}$ DTT, $75 \mathrm{mM} \mathrm{NaCl}$, and $0.05 \%$ Tween-20. The system for inhibition study consisted of $50 \mathrm{mM}$ Bis-Tris buffer ( $\mathrm{pH} 7.2$ ), $100 \mathrm{mM} \mathrm{NaCl}, 3 \mathrm{mM}$ EDTA, 1 mM DTT, 1 vol. \% DMSO, inhibitor and enzyme. The mixture was thermostated at $30{ }^{\circ} \mathrm{C}$ during $5 \mathrm{~min}$ and reaction was started by adding the substrate (pNPP) at concentration near $K_{\mathrm{m}}$ value for each of the enzymes. The activity of enzymes was measured spectrophotometrically at $410 \mathrm{~nm}$. The molar extinction coefficient of $18300 \mathrm{M}^{-1} \mathrm{~cm}^{-1}$ was used for calculation of $p$-nitrophenol concentration.

GST from equine liver and human recombinant GSTA1-1 was purchased from Sigma-Aldrich. Before use in the experiments, $0.25 \mathrm{mg}$ of GST from equine liver was diluted in $1 \mathrm{ml}$ of distillated water, and $25 \mu \mathrm{L}$ of GSTA1-1 was diluted in $1 \mathrm{ml}$ of solution consisted of $50 \mathrm{mM}$ Tris- $\mathrm{HCl}$ buffer (ph 7.5), $50 \mathrm{mM} \mathrm{NaCl}, 1 \mathrm{mM}$ DTT, $5 \mathrm{mM}$ EDTA and 50 vol. $\%$ glycerol. The rhodanine derivatives were dissolved in DMSO. In vitro studies were carried out in system consisting of $0.1 \mathrm{M}$ sodium-phosphate buffer (pH 6.5), $0.1 \mathrm{mM}$ EDTA, $2.5 \mathrm{vol}$. \% DMSO, water, $20 \mu \mathrm{l}$ of enzyme solution and inhibitor. After incubation of this mixture at $25^{\circ} \mathrm{C}$ during $5 \mathrm{~min}$, the reaction was started by addition $200 \mu \mathrm{L}$ of $10 \mathrm{mM}$ reduced L-glutathione (GSH) and $20 \mu \mathrm{L}$ of $100 \mu \mathrm{mM}$ 1-chloro-2,4-dinitrobenzene (CDNB). The enzyme activity was monitored spectrophotometrically at $340 \mathrm{~nm}$. The molar extinction coefficient of $9600 \mathrm{M}^{-1} \mathrm{~cm}^{-1}$ was used for calculation of dinitrophenyl-S-glutathione concentration [48].

\section{Molecular docking calculation}

Crystal structures of open and closed conformation of VE-PTP (PDB code 2AHS and 2H02, respectively) and GSTA1-1 (PDB code 6ATO) were downloaded from PDB server (https://www.rcsb.org) [49]. Before docking calculation, the ligands, water molecules and amino acids conformers were removed from obtained PDB files. The structure of thiazole-containing rhodanine derivatives were drawn using MarvinSketch [50] and optimized with MMFF94s force field in Avogadro software [51]. Docking files were prepared using AutoDockTools (version 1.5.6) [52]. The docking calculations were carried out by Autodock Vina software [53]. The models visualizations and analysis was performed using Discovery Studio 3.5 Visualizer (Accelrys Inc., San Diego, CA, USA).

\section{Notes}

Acknowledgements. This research was supported by the National Academy of Sciences of Ukraine (grant for research project of young scientists by National Academy of Sciences of Ukraine № 76-09/04-2020).

\section{The authors declare no conflict of interest.}

Author contributions. O. L. K.: conceptualization, supervision, molecular docking simulation, writing-original draft. V. O. S.: synthesis of compounds, investigation, formal analysis. Y.V.S.: investigation of bioactivity. V. M. B.: investigation of bioactivity. D. M. H.: 
investigation. S. G. P.: synthesis of compounds, analysis. V.S. B.: supervision, writing-review and editing. A. I. V. conceptualization, supervision, writing-review and editing.

\section{References}

1. Sharma, P. C.; Bansal, K. K.; Sharma, A.; Sharma, D.; Deep, A. Thiazole-containing compounds as therapeutic targets for cancer therapy. Eur. J. Med. Chem. 2020, 188, 112016.

2. Mishra, I.; Mishra, R.; Mujwar, S.; Chandra, P.; Sachan, N. A retrospect on antimicrobial potential of thiazole scaffold. $J$. Heterocycl. Chem. 2020, 57, 2304-2329.

3. Singh, I. P.; Gupta, S.; Kumar, S. Thiazole compounds as antiviral agents: An update. Med. Chem. 2020, 16, 4-23.

4. Kaminskyy, D.; Kryshchyshyn, A.; Lesk, R. Recent developments with rhodanine as a scaffold for drug discovery. Expert Opin. Drug Discov. 2017, 12, 1233-1252.

5. Nanjan, M. J.; Mohammed, M.; Kumar, B. R. P.; Chandrasekar M. J. N. Thiazolidinediones as antidiabetic agents: a critical review. Bioorg. Chem. 2018, 77, 548-567.

6. Bataille C. R.; Brennan M. B.; Byrne S.; Davies S. G.; Durbin M.; Fedorov O.; Huber K. V. M.; Jones A. M.; Knapp S.; Nadali A.; Quevedo C. E.; Russell A.; Walker R. G.; Westwood R.; Wynne G. M. Thiazolidine derivatives as potent and selective inhibitors of PIM kinase family. Bioorg. Mad. Chem. 2017, 25, 2657-2665.

7. Sawaguchi, Y.; Yamazaki, R.; Nishiyama, Y.; Sasai, T.; Mae, M.; Abe, A.; Yaegashi, T.; Nishiyama, H.; Matsuzaki, T. Rational design of a potent pan-Pim kinases inhibitor with a rhodaninebenzoimidazole structure. Anticancer Res. 2017, 37, 4051-4057.

8. Huang, M.-J.; Cheng, Y.-C.; Liu C.-R.; Lin S.; Liu H. E. A smallmolecule c-Myc inhibitor, 10058-F4, induces cell-cycle arrest, apoptosis, and myeloid differentiation of human acute myeloid leukemia. Exp. Hematol. 2006, 34, 1480-1489.

9. Lin, C. P.; Liu, J.-D.; Chow, J.-M.; Liu, C.-R.; Liu, H.-E. Smallmolecule c-Myc inhibitor, 10058-F4, inhibits proliferation, downregulation human telomerase reverse transcriptase and enchances chemosensitivity in human hepatocellular carcinoma cell. Anticancer Drugs. 2007, 18, 161-170.

10. Vatolin, S.; Phillips, J. G.; Jha, B. K.; Govindgari, S.; Hu, J.; Grabowski, D.; Parker, Y.; Lindner D. J.; Zhong, F.; Distelhorst, C. W.; Smith, M. R.; Cotta, C.; Xu, Y.; Chilakala, S.; Kuang, R. R.; Tall, S.; Reu, F. J. Novel protein disulfide isomerase inhibitor with anticancer activity in multiple myeloma. Cancer. Res. 2016, 76, 3340-3350.

11. Furdas, S. D.; Shekfeh, S.; Knnan, S.; Sippl, W.; Jung, M. Rhodaninecarboxylic acids as novel inhibitors of histone acetyltransferases. Med. Chem. Commun. 2012, 3, 305-311.

12. Li, P.; Zhang, W.; Jiang, H.; Li, Y.; Dong, C.; Chen, H.; Zhang, K.; $\mathrm{Du}, \mathrm{Z}$. Design, synthesis and biological evaluation of benzimidazolerhodanine conjugates as potent topoisomerase II inhibitors. Med. Chem. Comm. 2018, 9, 1194-1205.

13. Bernardo, P. H.; Sivaraman, T.; Wan, K.-F.; Xu, J.; Krishnamoorthy, J.; Song, C. M.; Tian, L.; Chin, J. S. F.; Lim, D. S. W.; Mok, H. Y. K.; Yu, V. C.; Tong, J. C.; Chai, C. L. L.Synthesis of a rhodaninebased compound library targeting Bcl-XL and Mcl-1. Pure Appl. Chem. 2011, 83, 723-731.

14. Zervosen, A.; Lu, W.-P.; Chen, Z.; White, R. E.; Demuth, T. P., Jr.; Frère, J. M. Interactions between penicillin-binding proteins (PBPs) and two novel classes of PBP inhibitors, arylalkylidene rhodanines and arylalkylidene iminothiazolidin-4-ones. Antimicrob. Agents Chemother. 2004, 48, 961969.

15. Grant, E. B.; Guiadeen, D.; Baum, E. Z.; Foleno, B. D.; Jin, H.; Montenegro, D. A.; Nelson, E. A.; Bush, K.; Hlasta, D. J. The synthesis and SAR of rhodanines as novel class $\mathrm{C} \beta$-lactamase inhibitors. Bioorg. Med. Chem. Lett. 2000, 10, 2179-2182.

16. Xiang, Y.; Chen, C.; Wang, W.-M.; Xu, L.-W.; Yang, K.-W.; Oelschlaeger, P.; He, Y. Rhodanine as a potent scaffold for the development of broad-spectrum metallo- $\beta$-lactamase inhibitors. ACS Med. Chem. Lett. 2018, 9, 359-364.

17. Alonso, A.; Sasin, J.; Bottini, N.; Friedberg, I.; Friedberg, I.; Osterman, A.; Godzik, A.; Hunter, T.; Dixon, J.; Mustelin, T. Protein tyrosine phosphatases in the human genome. Cell. 2004, 117, 699711.

18. He, R.-j.; Yu, Z.-h.; Zhang, R.-y.; Zhang, Z.-y. Protein tyrosine phosphatases as potential therapeutic targets. Acta Pharmacol. Sin. 2014, 35, 1227-1246.
19. Koren, S.; Fantus, I. G. Inhibition of the protein tyrosine phosphatase PTP1B: potential therapy for obesity, insulin resistance and type-2 diabetes mellitus. Best Pract. Res. Endocrinol. Metab. 2007, 21, 621640.

20. Zhu, S.; Bjorge, J. D.; Fujita, D. J. PTP1B contributes to the oncogenic properties of colon cancer cells through Src activation. Cancer. Res. 2007, 67, 10129-10137.

21. Hoekstra, E.; Das, A. M.; Swets, M.; Cao, W.; van der Woude, J.; Bruno, M. J.; Peppelenbosch, M. P.; Kuppen, P. J. K.; ten Hagen, T. L. M.; Fuhler, G. M. Increased PTP1B expression and phosphatase activity in colorectal cancer results in a more invasive phenotype ans worse patient outcome. Oncotarget. 2016, 7, 21922-21938.

22. Lessard, L.; Labbé, D. P.; Deblois, G.; Bégin, L. R.; Hardy, S.; MesMasson, A.-M.; Saad, F.; Trotman, L. C.; Giguére, V.; Tremblay, M. L. PTP1B is an androgen receptor-regulated phosphatase that promotes the progression of prostate cancer. Cancer. Res. 2012, 72, 1529-1537.

23. Cho, C. Y.; Koo, S.-H.; Wang, Y.; Callaway, S.; Hedrick, S.; Mak, P. A.; Orth, A. P.; Peters, E. C.; Saez, E.; Montminy, M.; Schultz, P. G.; Chanda S. K. Identification of the tyrosine phosphatase PTP-MEG2 as an antagonist of hepatic insulin signaling. Cell. Metab. 2006, 3, 367-378.

24. Zhang, S.; Liu, S.; Tao, R.; Wei, D.; Chen, L.; Shen, W.; Yu, Z.-H.; Wang, L.; Jones, D. R.; Dong, X. C.; Zhang, Z.-Y. A highly selective and potent PTP-MEG2 inhibitor with therapeutic potential for type 2 diabetes. J. Am. Chem. Soc. 2012, 134, 18116-18124.

25. Xu, M.-J.; Sui, X.; Zhan, R.; Dai, C.; Krantz, S. B.; Zhao, Z. J. PTPMEG2 is activated in polycythemia vera erythroid progenitor cells and is required for growth and expansion of erythroid cells. Blood. 2003, 102, 4354-4360.

26. Navarrete-Vazquez, G.; Paoli, P.; León-Rivera, I.; VillalobosMolina, R.; Medina-Franco, J.; Ortiz-Andrade, R.; Estrada-Soto, S.; Camici, G.; Diaz-Coutiño, D.; Gallardo-Ortiz, I.; Martinez-Mayorga, K.; Moreno-Díaz, H. Synthesis, in vitro and computational studies of protein tyrosine phosphatase $1 \mathrm{~B}$ inhibition of a small library of 2 arylsulfonylaminobenzothiazoles with antihyperglycemic activity. Bioorg. Med. Chem. 2009, 17, 3332-3341.

27. Combs, A. P. Recent advances in the discovery of competitive protein tyrosine phosphatase $1 \mathrm{~B}$ inhibitors for the treatment of diabetes, obesity, and cancer. J. Med. Chem. 2010, 53, 2333-2344.

28. Hidalgo-Figueroa, S.; Estrada-Soto, S.; Ramírez-Espinosa, J. J.; Paoli, P.; Lori, G.; León-Rivera, I.; Navarrete-Vázquez, G. Synthesis and evaluation of thiazolidine-2, 4-dione/benzazole derivatives as inhibitors of protein tyrosine phosphatase 1B (PTP-1B): Antihyperglycemic activity with molecular docking study. Biomed. Pharmacother. 2018, 107, 1302-1310.

29. Liu, H.; Sun, D.; Du, H.; Zheng, C.; Li, J.; Piao, H.; Li, J.; Sun, L. Synthesis and biological evaluation of tryptophan-derived rhodanine derivatives as PTP1B inhibitors and anti-bacterial agents. Eur. J. Med. Chem. 2019, 172, 163-173.

30. Bhattarai, B.; Kafle, B.; Hwang, J.-S.; Khadka, D.; Lee, S.-M.; Kang, J.-S.; Ham, S. W.; Han, I.-O.; Park, H.; Cho, H. Thiazolidinedione derivatives as PTP1B inhibitors with antihyperglycemic and antiobesity effects. Bioorg. Med. Chem. Lett. 2009, 19, 6161-6165.

31. Mahapatra, M. K.; Kumar, R.; Kumar, M. Synthesis, biological evaluation and in silico studies of 5-(3-methoxybenzylidene) thiazolidine-2,4-dione analogues as PTP1B inhibitors. Bioorg. Chem. 2017, 71, 1-9.

32. Chen, Y. T.; Seto, C. T. Divalent and trivalent $\alpha$-ketocarboxylic acids as inhibitors of protein tyrosine phosphatases. J. Med. Chem. 2002, 45, 3946-3952.

33. Li, X.; Bhandari, A.; Holmes, C. P.; Szardenings, A. K. $\alpha, \alpha$-Difluoro$\beta$-ketophosphonates as potent inhibitors of protein tyrosine phosphatase 1B. Bioorg. Med. Chem. Lett. 2004, 14, 4301-4306.

34. Wang, Q.; Zhu, M.; Zhu, R.; Lu, L.; Yuan, C.; Xing, S.; Fu, X.; Mei, Y.; Hang, Q. Exploration of $\alpha$-aminophosphonate N-derivatives as novel, potent and selective inhibitors of protein tyrosine phosphatases. Eur. J. Med. Chem. 2012, 49, 354-364.

35. Patel, D.; Jain, M.; Shah, S. R., Bahekar, R.; Jadav, P.; Joharapurkar, A.; Dhanesha, N.; Shaikh, M.; Sairam K. V. V. M.; Kapadnis, P. Discovery of potent, selective and orally bioavailable triarylsulfonamide based PTP1B inhibitors. Bioorg. Med. Chem. Lett. 2012, 22, 1111-1117.

36. Campochiaro, P. A.; Sophie, R.; Tolentino, M.; Miller, D. M.; Browning, D.; Boyer, D. S.; Heier, J. S.; Gambino, L.; Withers, B.; Brigell, M. Treatment of diabetic macular edema with an inhibitor of vascular endothelial-protein tyrosine phosphatase that activates Tie2. Ophthalmology. 2015, 122, 545-554. 
37. Campochiaro, P. A.; Peters, K. G. Targeting Tie2 for treatment of diabetic retinopathy and diabetic macular edema. Curr. Diab. Rep. 2016, 16, 126 .

38. Shen, J.; Frye, M.; Lee, B. L.; Reinardy, J. L.; McClung, J. M.; Ding, K.; Kojima, M.; Xia, H.; Seidel, C.; Lima e Silva, R.; Dong, A.; Hackett, S. F.; Wang, J.; Howard, B. W.; Vestweber, D.; Kontos, C. D.; Peters, K. G.; Campochiaro, P. A. Targeting VE-PTP activates TIE2 and stabilizes the ocular vasculature. J. Clin. Invest. 2014, 124 4564-4576.

39. Ozen, C.; Unlusoy, M. C.; Aliary, N.; Ozturk, M.; Dundar, O. B Thiazolidinedione or rhodanine a study on synthesis and anticancer activity comparison of novel thiazole derivatives. J. Pharm. Pharm. Sci. 2017, 20, 415-427.

40. Kaur, G.; Gupta, S. K.; Singh, P.; Ali, V.; Kumar, V.; Verma, M. Drug-metabolizing enzymes: role in drug resistance in cancer. Clin. Transl. Oncol. 2020, 22, 1667-1680.

41. Hanna, P. E.; Anders, M. W. The mercapturic acid pathway. Crit Rev. Toxicol. 2019, 49, 819-929.

42. Hayes, J. D.; Flanagan, J. U.; Jowsey, I. R. Glutathione transferases. Annu. Rev. Pharmacol. Toxicol. 2005, 45, 51-88.

43. Shultz, M.; Dutta, S.; Tew, K. D. Inhibitors of glutathione Stransferases as therapeutic agents. Adv. Drug Deliv. Rev. 1997, 26, 91-104.

44. Allocati, N.; Masulli, M.; Ilio, C. D.; Federici, L. Glutathione transferases: substrates, inhibitors and pro-drugs in cancer and neurodegenerative diseases.Oncogenesis. 2018, 7, 1-15

45. Sun, L.; Wang, P.; Xu, L.; Gao, L.; Li, J.; Piao, H. Discovery of 1, 3 diphenyl-1H-pyrazole derivatives containing rhodanine-3-alkanoic acid groups as potential PTP1B inhibitors. Bioorg. Med. Chem. Lett. 2019, 29, 1187-1193.
46. Sinenko, V. O.; Slivchuk, S. R.; Pil'o, S. G.; Raenko, G. F.; Brovarets, V. S. Synthesis of new 1,3-thiazole derivatives from 2(5)hydroxyalkyl-1,3-thiazole-5(2)-carbaldehydes. Russ. J. Gen. Chem. 2016, 86, 1597-1603.

47. Balchin, D.; Fanucchi, S.; Achilonu, I.; Adamson, R. J.; Burke, J.; Fernandes, M.; Gildenhuys, S.; Dirr, H. W. Stability of the domain interface contributes towards the catalytic function at the $\mathrm{H}$-site of class alpha glutathione transferase A1-1. Biochim. Biophys. Acta. 2010, 1804, 2228-2233.

48. Van der Aar E. M.; Buikema D.; Commandeur J. N.; te Koppele J. M.; van Ommen B.; van Bladeren P. J.; Vermeulen N. P. Enzyme kinetics and substrate selectivities of rat glutathione $S$-transferase isoenzymes towards a series of new 2-substituted 1-chloro-4nitrobenzenes. Xenobiotica. 1996, 26, 143-155.

49. Berman H. M.; Westbrook J.; Feng Z.; Gilliland, G.; Bhat, T. N.; Weissig, H.; Shindyalov, I. N.; Bourne P. E. The Protein Data Bank. Nucleic Acids Res. 2000, 28, 235-242.

50. MarvinSketch 5.2.4, 2009, ChemAxon [Internet]. Available from: http://www.chemaxon.com (accessed on October 22, 2020).

51. Hanwell M. D.; Curtis D. E.; Lonie D. C.; Vandermeersch T.; Zurek E.; Hutchison G. R. Avogadro: an advanced semantic chemical editor, visualization, and analysis platform. J. Cheminform. 2012, 4, 17.

52. Sanner, M. F. Python: A programming language for software integration and development. J. Mol. Graph. Model. 1999, 17, 57-61.

53. Trott O.; Olson A. J. AutoDock Vina: improving the speed and accuracy of docking with a new scoring function, efficient optimization and multithreading. J. Comput. Chem. 2011, 31, 455461.

\title{
Синтез та оцінка нових тіазоловмісних роданін-3-алканових кислот як інгібіторів протеїнтирозинфосфатаз та глутатіон-S-трансфераз
}

\author{
О. Л. Кобзар, В. О. Синенко, Ю. В. Шульга, В. М. Булденко, Д. М. Година, С. Г. Пільо, В. С. Броварець, А. І. Вовк
}

Інститут біоорганічноїхімї та нафтохімї ім. В. П. Кухаря НАН Украӥни, вул. Мурманська, 1, Київ, 02094,Украӥна.

Резюме: Тіазоловмісні похідні роданін-3-алканової кислоти, модифіковані залишками пропанової чи ундеканової кислот, синтезовано та оцінено як інгібітори деяких протеїнтирозинфосфатаз та глутатіон-S-трансфераз. Сполуки отримано за реакцією Кновевенагеля взаємодією відповідних роданінів 3 альдегідами. Встановлено, що роданіни з довшим карбоксильованим $N$-алкільним ланцюгом інгібують активність РТР1В, МЕG1, MEG2 та VE-PTP, а також GST з печінки коня та людську рекомбінантну GSTA1-1 зі значеннями $\mathrm{IC}_{50}$ у низькому мікромолярному діапазоні. Інгібувальний ефект на активність протеїнтирозинфосфатаз залежав від замісника в 2 положенні тіазолового кільця, тоді як природа замісників у положенні 2 та 4 мала незначний вплив на інгібувальну активність сполук щодо глутатіон-S-трансфераз. Найкраща сполука, 11-(5-\{[2-(4хлорфеніл)-1,3-тіазол-5-іл]метиліден \} \}-4-оксо-2-сульфаніліден-1,3-тіазолідин-3-іл)ундеканова кислота, продемонструвала конкурентний тип інгібування VE-PTP. У випадку GST з печінки коня сполука виявилась змішаним інгібітором при використанні GSH як субстрату та неконкурентним інгібітором у разі CDNB. Результати молекулярного докінгу вказують на те, що інгібітор може займати активний центр протеїнтирозинфосфатази VE-PTP, тоді як інгібування людської рекомбінантної GSTA1-1 може бути пояснено розташуванням похідної роданіну між $C$ - та $N$-кінцевими доменами однієї з субодиниць ферменту.

Ключові слова: роданін; тіазол; протеїнтирозинфосфатаза; глутатіон-S-трансфераза; інгібування ферменту; молекулярний докінг. 